\title{
Um agente do Império brasileiro em Londres: William Henry Clark e o fim da política da escravidão saquarema
}

\author{
An agent of the Brazilian Empire in London: William Henry Clark and the end of \\ the policy of slavery Saquarema
}

Henrique Antonio Ré ${ }^{1}$

\section{RESUMO}

Em meados da década de 1860, depois dos episódios relativos à "Questão Christie" e do subsequente rompimento das relações diplomáticas entre Brasil e Grã-Bretanha, agentes do Império brasileiro atuaram internacionalmente para reduzir as hostilidades antiescravistas britânicas dirigidas ao Brasil e pedir a revogação da Lei Aberdeen, ainda em vigor nos statute books britânicos. William Henry Clark, colunista do Jornal do Commercio e homem de negócios em Londres, desempenhou um papel importante na imprensa britânica ao lançar escritos esclarecendo as posições do novo governo liberal que acabara de subir ao poder no Brasil e como ele pretendia dar encaminhamento à sua plataforma emancipacionista.

Palavras-chave: William Henry Clark. Questão Christie. Imprensa. Escravidão. Emancipação.

\section{ABSTRACT}

In the mid-1860s, after the "Christie Question" and subsequent disruption of diplomatic relations between Brazil and Britain, agents of the Brazilian Empire acted internationally to reduce British antislavery hostilities directed at Brazil and call for repeal of the Law Aberdeen, still in force in the British statute books. William Henry Clark, a columnist for the Jornal do Commercio and a business man in London, played an important role in the British press by publishing writings clarifying the positions of the new liberal government that had just come to power in Brazil and how it intended to give way to his emancipationist platform.

Keywords: William Henry Clark. Christie Question. Press. Slavery. Emancipation.

1 Doutor em Sociologia pela Universidade Estadual de Campinas. Pós-doutorando no Departamento de História da Universidade de São Paulo.E-M ail: henrique.re@ usp.br 
Em meados de 1863 o Brasil rompeu relações diplomáticas com a Grã-Bretanha. 0 imbróglio entre os dois países vinha de alguns anos e era motivado por uma série de fatores, alguns relacionados a problemas comerciais, outros à situação dos africanos escravizados ilegalmente no Brasil e à diretriz antiescravista britânica. Todavia, oficialmente, o estopim da crise ocorreu com as ordens do então ministro britânico no Rio de Janeiro, William Dougal Christie, quando, nos primeiros dias de 1863, ordenou que os cruzadores britânicos detivessem navios mercantes brasileiros como forma de represália pelo descaso com que as autoridades ministeriais teriam tratado o naufrágio de um barco britânico no Rio Grande do Sul e um desentendimento entre marinheiros britânicos e policiais brasileiros no Rio de J aneiro. Depois de mediações internacionais, de certa teimosia do Imperador $D$. Pedro II e de uma série de esforços diplomáticos frustrados, em junho de 1863, desgostoso com a maneira pela qual o governo britânico lidava com a questão, Carvalho Moreira, então ministro brasileiro em Londres, foi orientado a pedir seus passaportes e se retirar da cidade. Reciprocamente, 0 mesmo ocorreu com a Legação britânica no Rio de Janeiro (SILVA, 2003, p. 295-307; GRAHAM, 1962).

A historiografia já questionou as alegações de Christie sobre os motivos que desencadearam suas ações e apresentou evidências de que o ministro britânico tomara aqueles dois incidentes apenas como pretextos para camuflar seus propósitos antiescravistas (CONRAD, 1978, p. 88-100; GRAHAM, 1962; MAMIGONIAN, 2017, p. 366-376; PARRON, 2011, p. 322).

De todo modo, depois de Carvalho Moreira se retirar de Londres, Christie, atendendo às ordens do ministro do Foreign Office, retornou à Grã-Bretanha. De fato, a questão era delicada. Vários assuntos que motivavam a discórdia entre os dois países, mas que vinham sendo tratados de forma relativamente serena, ganharam uma nova dimensão diante da animosidade despertada pela crise. Além de uma reparação à honra do país, que havia sido afetada pelas represálias, o Brasil passou a reivindicar a revogação da Lei Aberdeen, uma vez que o tráfico de escravos estava extinto há quase uma década, mas a lei continuava em vigor nos statute-books britânicos. A Grã-Bretanha, por seu lado, pleiteava um novo tratado anti-tráfico e um novo tratado comercial; além disso, motivada provavelmente pelos últimos eventos da Guerra Civil Norte-Americana, ela também agia para forçar o Brasil a encaminhar medidas antiescravistas (CONRAD, 1978, p. 88-100).

Foi nesse ambiente de crise diplomática e política entre os dois países que um gentleman inglês, com fortes ligações financeiras com o Brasil, passou a atuar na imprensa britânica para difundir interpretações simpáticas ao governo brasileiro e criticar as medidas repressivas adotadas pelo governo britânico. A atuação desse agente foi emblemática, pois, embora ele recebesse algum tipo de remuneração, não se tratava meramente de um sujeito de renome disposto a alugar seus dotes de escritor para defender uma causa que Ihe era indiferente - aliás, seus escritos geralmente eram 
lançados sob pseudônimo ou anonimamente. As transações comerciais e financeiras entre os dois países haviam atingido patamares inéditos, e esse agente também representava grupos britânicos que tinham interesse de preservá-las de qual quer contaminação e idiossincrasia política.

Este artigo explora as ligações desse agente com a política, a imprensa e a diplomacia brasileira. Além disso, procura destacar como seus escritos na imprensa da Grã-Bretanha no início da década de 1860 auxiliaram o governo brasileiro a criticar os procedimentos britânicos naquela que ficou conhecida como a "Questão Christie" e a pressionar o governo de Sua Majestade a revogar a Lei Aberdeen. Em linhas gerais, esses escritos também já apresentavam as estratégias que o Partido Liberal brasileiro (ou Progressista) estava colocando em execução para enfrentar a "política da escravidão" montada nas décadas anteriores pelos saquaremas (PARRON, 2011).

Esses elementos permitem afirmar que alguns anos antes do Conselho de Estado brasileiro oficialmente discutir o encaminhamento da questão do "elemento servil", a diplomacia e um grupo de liberais brasileiros já estavam atuando no campo internacional para aplacar a hostilidade da diretriz antiescravista britânica e conquistar apoio para a implantação das medidas emancipacionistas brasileiras. (Esse assunto será retomado na conclusão).

As principais fontes utilizadas neste artigo são, em geral, textos publicados na Grã-Bretanha na primeira metade da década de 1860, por ocasião dos debates da "Questão Christie", e que são praticamente desconhecidos da historiografia. Obviamente, também são utilizadas outras fontes brasileiras e britânicas para o cruzamento de informações.

\section{Imprensa e Ação Diplomática na Década de 1860}

No século XIX, o governo brasileiro lançou mão de uma série de medidas para influenciar a opinião pública internacional, especialmente a europeia. 0 objetivo era variado, mas, em geral, visava a angariar a simpatia do público para o único império das Américas, cujo imperador ilustrado descendia de importantes linhagens dinásticas do Velho Continente. Mas a atuação na imprensa internacional também tinha a intenção de expressar os posicionamentos do governo brasileiro em relação a questões políticas, diplomáticas e econômicas, bem como informar minimamente sobre os avanços civilizacionais conquistados pelo país continental da América do Sul.

Em casos específicos, a publicação de textos favoráveis ao Império, e o pagamento de agentes, escritores e órgãos de imprensa internacionais tinham o propósito de combater visões consideradas pelos brasileiros como distorcidas ou abusivas. Isso pode ser facilmente constatado na década de 1860, quando o Brasil subsidiou quase duas dezenas de órgãos de imprensa e mais de trinta escritores 
franceses para melhorar a imagem do Império naquele país, combater alguns autores comprometidos com o abolicionismo radical e apresentar o ponto de vista brasileiro sobre a Guerra do Paraguai. Em outras situações, a propaganda laudatória, como no caso do material divulgado em regiões da Alemanha, tinha a intenção de seduzir imigrantes a cruzar o Atlântico e se instalar nas terras brasileiras (ZENHA, 2003, p. 435-436; CHRISTIE, 1863).

Contudo, o financiamento de publicações internacionais também era uma forma de intervir no debate político desses países, especialmente quando questões relativas ao Brasil estavam em discussão. Numa época em que as revistas e jornais impressos eram os principais veículos de informação e, por conseguinte, imprescindíveis para a formação da opinião pública, atuar nesses órgãos de imprensa tomava-se quase uma obrigatoriedade para qualificar o debate e apresentar pontos de vista divergentes. Esse expediente, aliás, estava longe de ser uma exclusividade brasileira. A historiografia há muito já demonstrou como o Foreign Office britânico financiou generosamente jornais e jornalistas brasileiros, especialmente nas décadas de 1840 e 1850, para combater o tráfico de escravos e apresentar uma visão mais favorável às ações repressivas dos cruzadores da Royal Navy (BETHELL, 1976, p. 296-297; ELTIS, 1987, p. 115; HUGH, 1997, p. 740).

As ações na imprensa internacional, entretanto, envolviam um montante considerável de verba, que nem sempre podia ser claramente especificado no orçamento imperial. Em 1862, por exemplo, dois senadores brasileiros, Silveira da Motta e J equitinhonha, interpelaram o ministro da Justiça sobre a falta de clareza nos critérios adotados na destinação da verba do "fundo secreto", originalmente voltado para o combate ao tráfico de escravos africanos. Era sabido que o tráfico estava extinto desde meados da década anterior, mas o governo brasileiro ainda mantinha em seu orçamento uma rubrica destinando vários contos de réis para a repressão desse comércio. Essa anomalia também não passou despercebida a Christie, que acusou o governo brasileiro de acobertar sob aquela rubrica suas ações de propaganda na Europa (Anais do Senado, 16 ago. 1862, p. 93-94; CHRISTIE, 1863). De fato, a questão envolvia uma soma vultosa de recursos. 0 orçamento encaminhado para a Câmara dos Deputados em 1862, referente ao exercício de 1863-1864, previa que 174:000\$000 seriam destinados à “despesa secreta e repressão do tráfico de africanos" (Collecção das Leis do Imperio do Brasil, 1862, p. 26).

A crítica de Christie não era desinteressada. Desde que o ex-ministro britânico foi chamado de volta para a Grã-Bretanha, depois das represálias que ordenou contra navios mercantes brasileiros no início de 1863, ele entrou numa acirrada disputa de versões com o agente patrocinado pelo Império brasileiro. No final daquela década, Richard Burton, então cônsul em Santos, endossando as palavras de Christie, censurou asperamente "os propagandistas assalariados do Brasil e lacaios de sua legação" (BURTON, 2001, p. 42). 
A seguir, serão apresentadas evidências de como o governo brasileiro procurou interferir na opinião pública britânica, por meio de textos escritos por agentes subsidiados, para apresentar pontos de vista mais favoráveis ao Império, defender interesses políticos e econômicos, e se posicionar claramente sobre a nova diretriz antiescravista que estava sendo implantada.

\section{Agente do Império brasileiro}

O desafeto de Christie era seu conterrâneo e chamava-se William Henry Clark. Embora mantivesse contatos frequentes com os meios diplomáticos, jornalísticos e políticos brasileiros da segunda metade do século XIX, Clark, como era mais conhecido, ainda permanece um personagem relativamente obscuro, sobre o qual há pouca informação confiável. Não foi possível descobrir se Clark visitou ou morou no Brasil. Todavia, pela maneira como demonstrou conhecer os assuntos brasileiros, é inegável que possuía, além de relativa erudição, um bom conhecimento da história, da política, da situação coeva e dos problemas do Brasil, bem como fluência no português.

Clark se tornou correspondente do J ornal do Commercio em Londres no final da década de 1850 ou um pouco antes. É praticamente impossível estabelecer com precisão a data em que começou a enviar suas matérias, pois os correspondentes internacionais não assinavam suas colunas e o jornal fazia questão, na medida do possível, de manter o anonimato. Ele desempenhou essa função até sua morte, que ocorreu em 29 de setembro de 1881, em Dijon, quando regressava das águas termais de Badenweiler. O Jornal do Commercio mencionou em três ocasiões o seu falecimento, sempre enaltecendo suas virtudes de lealdade aos interesses do Brasil e sua capacidade de trabalho, que era desempenhado à maneira de um culto, pois dele não necessitava, já que possuía "largos meios de subsistência". A historiografia mencionou algumas vezes o seu falecimento, pois esse evento abriu as portas para que J oaquim Nabuco sucedesse Clark como correspondente do J ornal do Commercio no início da década de 1880 (J ornal do Commercio, 2 out. 1881, p. 1; 25 out. 1881, p. 2; 28 out. 1881, p. 1; MENDONÇA, 2006, p. 328-329; ALONSO, 2006, p. 136-137).

Por meio do cruzamento de informações, é possível saber que em 1859 Clark acompanhou a designação de Christie como ministro plenipotenciário para o Rio de Janeiro. Provavelmente influenciado por Carvalho Moreira, que fez gracejo com a indicação do ministro, dizendo que ele "aprendeu a diplomacia no território de Mosquito", o correspondente do Jornal do Commercio 
informou aos leitores que a recente indicação não era um "bom agouro para o Brasil" (MENDONÇA, p. 164; Jornal do Commercio, 7 nov. 1859, p. 1). ${ }^{2}$

No ano seguinte, aproveitando-se de uma visita que Christie realizara, em trajes considerados não protocolares, às princesas imperiais em Petrópolis, Clark lançou uma carta n' 0 Correio da Tarde ridicularizando o gesto do ministro:

\begin{abstract}
Na Europa nenhum ministro diplomático teria a lembrança e a sans façon de ir cumprimentar em seus palácios a membros da família reinante, de sobrecasaca, calça de cor e gravata encarnada.

No Brasil, segundo consta, assim praticava ultimamente o Sr. ministro inglês, com espanto da Sra. condessa de Barral, e grande pasmo de algumas pessoas que se achavam presentes, e entre elas um ministro de estado, que não acreditava o que via, e cuidava estar sob a pressão de um sonho (0 Correio da Tarde, 17 mar. 1860, p. 1).
\end{abstract}

Christie descobriu quem era o autor da carta anônima e alguns dias depois publicou uma resposta bastante agressiva em três jornais da Corte, sem mencionar o nome do gaiato, mas tratandoo como correspondente. Também procurou Sinimbu, o então ministro brasileiro dos Negócios Estrangeiros, para se queixar do artigo e de seu autor, que era agente pago da Legação brasileira e amigo de Carvalho Moreira. Começava aí a querela que se estenderia por vários anos (MENDONÇA, 2006, p. 164-165; 0 Correio da Tarde, 27 mar. 1860, p. 1; Jornal do Commercio, 28 mar. 1860, p. 2; Correio Mercantil, 28 mar. 1860, p. 2).

Com ef eito, Clark desenvolvia declaradamente trabalhos para a Legação brasileira na GrãBretanha, como se pode observar pelo catálogo da Exposição Internacional de Londres, em 1862. Na seção destinada aos "Comissários Estrangeiros em Exercício", aparece "Brasil - F. I. de Carvalho Moreira, Ministro brasileiro; Agente, W. H. Clark". ${ }^{3}$ Além de trabalhos para a Legação, Clark logo se tornou amigo de Carvalho Moreira, de quem desfrutava momentos de hospitalidade na famosa embaixada de Grosvenor Gardens (INTERNATIONAL EXHIBITION 1862, 1862, p. 13; NABUCO, 1963, p. 95; MENDONÇA, 2006, p. 283).

Ele manteve estreitas ligações com companhias inglesas que construíram ferrovias no Brasil e, por vezes, integrou suas diretorias. Nos primeiros anos da década de 1860, em boa parte de suas colunas no Jornal do Commercio há menções às reuniões da diretoria dessas companhias e críticas aos

\footnotetext{
20 território de Mosquito era uma referência à Costa dos Mosquitos, também conhecida como Mosquítia, entre as atuais Nicarágua e Honduras, que foi dominada pela Grã-Bretanha até 1894.

3 A expressão "agente", bastante utilizada no século XIX, não guarda correspondência com a noção relacionada à espionagem, surgida posteriormente. 0 "agente" era considerado como a pessoa que atuava nos, ou gerenciava os negócios de outras pessoas ou empresas. A designação de Clark como "agente" da embaixada brasileira na Exposição Internacional de Londres assume esse caráter.
} 
procedimentos políticos brasileiros, que se preocupavam mais com o atendimento dos pleitos dos grandes fazendeiros do que com o transporte da população e a saúde financeira dos empreendimentos. Ele também era um observador atento de outros investimentos britânicos no Brasil, como a mineração e a dívida pública. Clark também, segundo Christie, era membro do Reform Club, um clube londrino de cavalheiros, frequentado por whigs e radicais, que queriam se distinguir da velha aristocracia whig e geralmente estavam comprometidos com o livre-comércio (Jornal do Commercio, 14 mar. 1864, p. 1; 23 ago. 1864, p. 1; The Anglo-Brazilian Times, 8 maio 1878, p. 2; ALONSO, 2006, p. 136, 139; BURLINGHAM, 2005, p. 39).

As relações de Clark com os brasileiros, contudo, não se restringiram à diplomacia ou aos interesses comerciais e financeiros. Ele seguramente manteve relações com políticos, principalmente liberais, e também com governos que estivessem dispostos a utilizar seus serviços. Em 1873, por exemplo, João Batista Calógeras, um funcionário do Império, informou que Clark remetera cartas muitos importantes para o ministro da Agricultura, do governo conservador de Rio Branco (CARVALHO, 1959, p. 256).

Mas foi por ocasião da chamada "Questão Christie" que Clark assumiu um protagonismo incomum dentre os inúmeros agentes europeus patrocinados pelo governo brasileiro. Depois de ter caçoado dos trajes de Christie em 1860, dois anos mais tarde Clark lançou uma matéria no Jornal do Commercio criticando o governo britânico pela maneira diferente com que tratava o governo brasileiro em relação ao espanhol na questão do tráfico de escravos. Ele dizia ainda que as investidas de Christie, na questão dos africanos livres e dos escravos importados ilegalmente, estavam sendo contidas por Lorde John Russell, então secretário do Foreign Office. Clark nitidamente estava se imiscuindo na política, atacando as ações de Christie e gerando desavenças entre o ministro no Rio de Janeiro e seu superior em Londres. Como correspondente do Jornal do Commercio, ele estava seguramente exorbitando de suas funções (J ornal do Commercio, 26 maio 1862, p. 1).

Christie acusou o golpe e, em 6 de junho de 1862, escreveu uma carta furiosa para Russell denunciando o artigo de Clark. Ele chegou a insinuar que informações de sua correspondência com o Foreign Office, assinalada como "private", haviam vazado. Christie tinha ainda outra razão para suspeitar que estivesse sendo boicotado: era sabido que Clark mantinha relações políticas e pessoais com o próprio Russell (Christie a Russell, 6 de junho de 1862, National Archives, F.0. 84-1180, p. 182185) Posteriormente, em decorrência das investidas de Clark contra Christie e contra as próprias decisões de Russell, a amizade entre ambos se arrefeceu (MENDONÇA, 2006, p. 176).

Esta foi a primeira vez, entretanto, que o ministro britânico no Rio de Janeiro mencionou o nome do correspondente do J ornal do Commercio, suas conexões com a Legação brasileira em Londres 
e com os políticos liberais brasileiros. Christie também sugeriu que Clark era editor ou possuía conexões com a administração do Daily News, e sua atuação não tendia "a beneficiar as relações entre os dois governos". Definitivamente, Christie não estava entendendo a situação e os motivos pelos quais Clark o atacava:

O governo de Sua Majestade e o ministro de Sua Majestade nesta Corte poderiam esperar ajuda, em vez de contestação, à diretriz inglesa, especialmente em questões relativas ao tráfico de escravos e à escravidão, de um cavalheiro associado aos políticos liberais e a um respeitável jornal liberal (Christie a Russell, 6 de junho de 1862, F.0. 84-1180, p. 185. Todas as citações em língua estrangeira foram traduzidas pelo autor).

É bastante plausível que Christie tivesse aliados entre as fileiras liberais brasileiras, com quem trocava informações e discutia estratégias. Por isso, ele não conseguia entender o fogo amigo (MAMIGONIAN, 2017, p. 367). Na verdade, Christie não havia percebido que estava começando a ser elaborada uma diretriz emancipacionista liberal brasileira, que não se alinhava automaticamente à diretriz antiescravista internacional britânica. Isso só ficaria claro um ou dois anos mais tarde.

Depois desse episódio, entre 1863e 1864, por ocasião do rompimento das relações diplomáticas entre o Brasil e a Grã-Bretanha, Clark voltou a investir novamente contra Christie ao lançar quatro artigos no Daily News, sob o pseudônimo "A FRIEND TO BOTH COUNTRIES". Esses artigos foram respondidos por Christie no mesmo periódico, sob o pseudônimo "C.". Posteriormente, em 1865, sabendo que Christie estava organizando uma coletânea com os artigos publicados no Daily News, Clark então lançou anonimamente um opúsculo intitulado The relations of the British and Brazilian governments. Embora nenhum desses textos traga a assinatura de William Henry Clark, ele jamais negou a autoria que Ihe foi atribuída, embora tenha comentado sobre a publicação deles ( ornal do Commercio, 26 mar. 1865, p. 1). Portanto, aqui neste artigo, é assumido que tanto os artigos publicados no Daily News quanto o opúsculo lançado anonimamente, que serão analisados adiante, são de autoria de William Henry Clark. Esses textos são praticamente desconhecidos da historiografia brasileira e, salvo melhor juízo, nunca foram analisados.

\section{A Diretriz Emancipacionista dos Liberais Brasileiros}

Em meados de 1863, instado pelo Marquês de Olinda, então presidente do Conselho de Ministros, o imperador dissolveu a Câmara e convocou novas eleições. Depois de um longo domínio, havia chegado o momento dos conservadores cederem o lugar. A despeito das denominações que possam ser atribuídas aos novos detentores do poder (progressistas ou liberais), o que importa reter é que eles dominaram quase todos os assentos da Câmara em janeiro de 1864. Tão logo os deputados se 
reuniram, Olinda e seu gabinete renunciaram. Era mais coerente deixar o governo nas mãos dos novos chefes, que, desde 1862, costuravam com Pedro II uma maneira de derrotar os saquaremas. 0 imperador chamou, então, Zacarias de Góis para formar o novo gabinete ministerial. O Estado autoritário projetado pelos reacionários de 1837 deveria ser moderadamente reformado (NEEDELL, 2006, p. 218-220).

Em nota enviada a Zacarias um dia antes de ele assumir a presidência do Conselho de Ministros, o imperador Ihe chamou a atenção para a necessidade de se pensar "no futuro da escravidão no Brasil, para que não nos suceda o mesmo a respeito do tráfico de escravos". Essa nota foi escrita um ano depois do início das represálias autorizadas por Christie e um ano e três meses depois da Proclamação da Emancipação de Lincoln. Todavia, ela antecedia em três anos e meio o debate deste tema pelo Conselho de Estado (LYRA, 1977, p. 162; SALLES, 2008, p. 89).

Se bem explorado, o novo contexto político brasileiro, inaugurado a partir de meados de 1863 com a dissolução da Câmara, a convocação de novas eleições, e a consequente assunção dos liberais ao poder, poderia dar maior legitimidade aos pleitos brasileiros na Grã-Bretanha. Essa leitura do quadro político foi utilizada diligente e eficientemente pela diplomacia e pelos liberais brasileiros. 0 antigo partido escravista havia sido apeado do poder. Ainda que o breve governo de Zacarias tenha sido substituído em agosto de 1864 pelo de Francisco José Furtado, e este cedido o lugar posteriormente ao de Olinda em 1865, que, por sua vez, foi substituído novamente pelo de Zacarias em 1866, havia claramente uma orientação na diretriz antiescravista dos liberais. Chegara o momento dos liberais brasileiros negociarem com seus eventuais aliados britânicos.

A primeira concessão brasileira visava a não deixar dúvidas sobre as verdadeiras intenções dos novos ocupantes do poder. Em 24 de setembro de 1864, por meio do decreto 3.310, o governo de Francisco J osé Furtado concedeu a emancipação "a todos os africanos livres existentes no Império". A despeito da incoerência da redação do decreto, que emancipava pessoas livres, esse ato foi um aceno inequívoco ao governo britânico e encerrou uma disputa que durante vários anos indispusera os dois países (Collecção de Leis do Império do Brasil, 1864, p. 160-161).

Antes mesmo do Conselho de Estado começar oficialmente a discutir o tema das medidas emancipacionistas, era o momento de agir no plano internacional e capitalizar o máximo possível a nova configuração política do Brasil.

Esse breve panorama é importante para se entender os textos lançados por Clark entre $1863 \mathrm{e}$ 1865 na Grã-Bretanha. Por uma questão de honra nacional, o Brasil - e principalmente D. Pedro II exigiam alguma reparação pelas ofensas de Christie, mas o rompimento das relações também serviu para o governo brasileiro pressionar diplomaticamente a Grã-Bretanha para que revogasse a Lei 
Aberdeen. Além disso, todos esses episódios foram habilmente trabalhados para constranger 0 gabinete britânico e o Foreign Office a reverem sua postura agressiva contra o Brasil e a concederem aos liberais brasileiros, que haviam acabado de subir ao poder, a chance de apresentar sua diretriz antiescravista.

Os dois primeiros artigos publicados por Clark no Daily News giravam em torno de duas questões: a necessidade de revogação do Bill Aberdeen para o restabelecimento das relações diplomáticas e as divergências textuais a respeito da convenção que Grã-Bretanha e Brasil tentaram estabelecer para dirimir reivindicações e queixas dos súditos de ambos os países. Nos dois casos, o autor martelava a diferença no tratamento dispensado ao Brasil em relação aos outros países. A Espanha não havia sido submetida a nada semelhante à Lei Aberdeen e os Estados Unidos estabeleceram uma convenção com a Grã-Bretanha baseada em termos mais equânimes. 0 Brasil reivindicava, portanto, um tratamento mais moderado e de acordo com sua posição no comércio internacional britânico (Daily News, 16 jul. 1863, p. 5; 20 jul. 1863, p. 3).

Contudo, a Lei Aberdeen foi a questão de maior destaque e à qual Clark dedicou expressões mais duras. Segundo ele, a manutenção dessa lei nos estatutos britânicos azedou as relações entre os dois países. Sem sua revogação, seria inútil esperar que o governo brasileiro se dispusesse a negociar amigavelmente outras questões com a Grã-Bretanha: "tratar-se-ia de um governo mesquinho e indigno se lambesse, como um spaniel, a mão que se levantou para golpeá-lo e feri-lo". Sem a revogação da referida Lei, pouco adiantaria o restabelecimento das relações diplomáticas, pois ainda persistiriam as desconfianças entre os dois países (Daily News, 16 jul. 1863, p. 5).

Desde 1845, quando o bill (Projeto de Lei) de Lorde Aberdeen foi aprovado, era a primeira vez que o Brasil estava em condições de se contrapor de alguma forma à Grã-Bretanha. 0 destempero das ordens de Christie, a arbitragem favorável ao Brasil emitida pelo rei dos belgas e uma opinião internacional que viu certo exagero na ação da Royal Navy acabaram por dar ao governo brasileiro legitimidade para questionar os procedimentos dos britânicos e, ao mesmo tempo, alguma força moral para reivindicar limites às ações antiescravistas britânicas no Brasil.

Se nos dois primeiros artigos, o objetivo foi repudiar o tratamento hostil e desigual que a GrãBretanha conferia ao Brasil, no artigo seguinte, de 1864, Clark começou a apresentar alguns resultados da nova administração brasileira. Contrariamente ao que dizia o Foreign Office, "há evidências de que o governo brasileiro está, tanto quanto possível, cumprindo seu dever por si mesmo" e libertando os emancipados. Depois de mecionar o número de emancipados que foram libertados nos últimos quatro anos, Clark diplomaticamente sugeriu que a Grã-Bretanha estava exagerando em suas reivindicações. Além disso, ela, de certo modo, também era responsável pela questão dos africanos emancipados: 
[...] repito que foi culpa - inteiramente culpa - do governo inglês que esses emancipados tenham sido colocados em sua condição atual. A provisão sob a qual eles foram consignados ao Brasil era uma provisão britânica, não brasileira. Ela foi imposta forçadamente pelo governo britânico, em nossos primeiros tratados sobre o tráfico de escravos com outros países, simplesmente para isentar a Inglaterra de problemas e despesas. [...] Sem dúvida, Brasil e Espanha são obrigados a respeitar e a garantir a liberdade desses africanos após o período de aprendizado. Mas quando a Inglaterra exige que o governo trace a história de cada emancipado, isso é impossível, especialmente num império tão grande como o Brasil, num país até então tão imperfeitamente organizado, e quando tal exigência vem de um governo que irritou e exasperou até o último grau (Daily News, 29 jul. 1864, p. 2).

Clark reconhecia que o Brasil, assim como a Espanha, tinha a obrigação de zelar pela liberdade dos africanos livres. Mas a Grã-Bretanha, na persecução de sua diretriz agressiva, desconsiderava as peculiaridades brasileiras mais elementares. Era necessário mais comedimento.

No último artigo da série do Daily News, Clark, por meio da citação de uma discussão parlamentar na Câmara dos Comuns, pediu novamente que a Grã-Bretanha mudasse a forma pela qual tratava o Brasil.

\begin{abstract}
A questão não é se todos os emancipados foram libertados ou se ainda existem escravos no Brasil, mas, como observou o Sr. Baring na Câmara dos Comuns em 18 de julho, "pela conciliação e pela linguagem gentil não é provável que renovemos as relações de amizade com o Brasil", que aumentemos nosso comércio, que obtenhamos justiça para os ingleses e que sejamos bem sucedidos nas negociações que ainda estão ocorrendo". Trata-se, acrescentou Baring, "de saber se devemos perseverar num curso de ação que traçou uma linha separando esse país e o Brasil, ou se devemos doravante adotar uma diretriz de conciliação em vez daquela diretriz insultante e irritante que perseguimos até agora" (Daily News, 4 ago. 1864, p. 3).
\end{abstract}

Numa questão diplomática e política tão relevante como essa, não se estava pedindo misericórdia. 0 que 0 agente estava sugerindo é que a Grã-Bretanha alterasse sua diretriz conflituosa em relação ao Brasil. Não se esperava apenas uma linguagem mais cortês nas relações diplomáticas; 0 que se demandava era uma mudança na diretriz antiescravista britânica voltada para o Brasil. Obviamente, numa questão dessa envergadura, Clark era apenas mais um elo de um acordo que estava sendo desenhado conjuntamente nos dois lados do Atlântico, acordo que necessitava de vários canais de interlocução.

Numa matéria para o J ornal do Commercio, Clark insinuou que os liberais britânicos (os whigs) estavam se movendo em direção à reconciliação, ainda que para isso contrariassem o gabinete liberal liderado por Palmerston: não tem motivo razoável de desavença com este Império. Recomenda, pois, que se revogue 0 
bill Aberdeen e se envie ao Rio de Janeiro um ministro bem escolhido (competent minister), que, armado daquela concessão, facilmente restabeleça em bases verdadeiras as relações entre os dois Estados (Jomal do Commercio, 17 nov. 1864, p. 2).

Mais ou menos nessa mesma época, o Brasil estabeleceu conexões com um dos aliados mais improváveis: a British and Foreign Anti-Slavery Society (BFASS). Em 21 de março, uma delegação do Comitê da BFASS se dirigiu à Embaixada do Brasil, em Londres, para entregar um Memorial ao Imperador brasileiro. Nessa ocasião, em decorrência do rompimento das relações entre os dois países, a delegação de abolicionistas não foi recebida pelo ministro brasileiro. 0 secretário da BFASS informou ao Sr. Andrada (Francisco Xavier da Costa Aguiar de Andrada), funcionário da embaixada, que muitos amigos no país estavam interessados no "movimento que estamos lançando agora para a abolição da escravidão no Brasil [sic]". A seguir, o Rev. Massie, outro integrante da delegação, preocupado com a suspensão das relações, afirmou que "na medida em que pudermos fazer qualquer coisa para promover o seu restabelecimento, estou certo de que todos os cavalheiros aqui estarão muito felizes em fazer tudo o que estiver ao nosso alcance para produzir tal resultado" (The AntiSlavery Reporter, 1 abr. 1864, p. 89-95).

Dois meses depois, a BFASS organizou o seu 25 Encontro Anual, em 20 de maio de 1864. Nesse evento ocorreu, entretanto, um fato inusitado. Antes do início dos trabalhos, um brasileiro pediu a palavra para tratar da questão da emancipação dos escravos no Brasil e fez claramente uma proposta ao Comitê:

Sr. Almeida Portugal disse que desejava apresentar antes do início do Encontro algumas palavras sobre o estado da Escravidão no Brasil [...]. Ele não podia deixar de dizer que, na medida em que sua humilde opinião Ihe permitia julgar, os brasileiros estavam ansiosos para ver a escravidão extinta de suas fronteiras [...] e os líderes parlamentares haviam apresentado propostas com vistas à extinção imediata da Escravidão. [...] Seu desejo era que eles [os integrantes do Encontro] levassem sua opinião sobre esta questão até o Comitê e organizassem uma reunião pública para apelar ao governo britânico para retirar do Parlamento a Lei em vigor, conhecida como Bill Aberdeen. [...] O Parlamento no Brasil agora estava trabalhando, e ele julgava que as leis apresentadas seriam aprovadas. [...] 0 governo adotaria outros meios para alcançar seu objetivo, ou seja, a liberdade dos escravos do Brasil, e ele esperava que isso fosse realizado com sucesso (The Anti-Slavery Reporter, 1 jun. 1864, p. 139-140).

Segundo Christie, o agente presente na reunião da BFASS, o Sr. Almeida Portugal, era tenente da Marinha brasileira (CHRISTIE, 1865, p. 74). Suas colocações, claramente, sugeriam uma proposta de acordo. 0 governo brasileiro adotaria medidas emancipacionistas e a BFASS atuaria pela revogação da Lei Aberdeen. E, de fato, a partir desse momento, a BFASS passou a defender o restabelecimento das relações entre os dois países, a revogação da Lei Aberdeen e o não envolvimento da Grã-Bretanha nos assuntos domésticos brasileiros. Por outro lado, a entidade antiescravista também passou a 
pressionar o governo brasileiro para que essas medidas fossem implantadas o mais rápido possível e julgou legítimo tentar interferir no alcance e no vigor delas.

Na sequência dessas ações e negociações, em 1865, Clark lançou The relations of the British and Brazilian governments. Este é um documento privilegiado para se entender o que os liberais brasileiros estavam pleiteando do governo britânico. Conforme o título sugere, o assunto principal a organizar toda a narrativa era a necessidade, segundo 0 autor, de se restabelecer as relações diplomáticas entre Brasil e Grã-Bretanha. Em suas mais de cinquenta páginas, Clark procurou deslegitimar a agressiva e hostil diretriz britânica contra o Brasil, e foi enfileirando argumentos, documentos e citações com 0 propósito de mostrar que tal procedimento não era plausível em vista das relações comerciais e financeiras dos dois países, nem encontrava respaldo na inclinação do povo britânico pelo Brasil. Além da argumentação favorável ao restabelecimento das relações, Clark também elaborou de forma bastante sutil - como a natureza da questão exigia - a fundamentação de uma diretriz emancipacionista brasileira, que encontraria a sua garantia nos liberais que acabaram de assumir o poder. A BFASS, seguindo seu acordo de atuar pelo restabelecimento das relações entre Brasil e GrãBretanha, repercutiu em seu periódico o lançamento deste opúsculo de Clark (The Anti-Slavery Reporter, 1 fev. 1865, p. 46-47).

Clark inicia seu opúsculo retomando ideias já expressas em seus artigos anteriores, como a suposta excepcionalidade do tratamento dispensado ao Brasil pela Inglaterra. Além disso, na visão do correspondente, ela deveria conter sua ingerência nos assuntos domésticos brasileiros:

O objetivo deste texto é promover o estabelecimento de relações boas e permanentes entre a Inglaterra e o Brasil, a partir do preceito da não-intervenção do governo inglês nos assuntos domésticos de outros países, que o Parlamento e o povo da Inglaterra parecem cada vez mais inclinados a obrigar o governo a adotar (CLARK, 1865, p. 3).

A estratégia de Clark era argumentar que o governo britânico estava tomando decisões que 0 isolavam de seu próprio "povo" e de seus representantes parlamentares. "A diretriz do governo inglês em relação ao Império brasileiro [...] deve se adequar às conexões que o povo inglês estabeleceu com o Império". Mas quais seriam essas conexões? Para Clark, sem dúvida, as comerciais e financeiras. 0 autor usou alguns parágrafos para expor os avanços do comércio e das finanças (empréstimos e financiamento de ferrovias) entre os dois países e o montante de libras nele envolvido. Com isso, Clark isolou a diretriz agressiva do Estado britânico, e afirmou que ela não estava conectada aos interesses do povo: "A peculiaridade, entretanto, das más relações entre os dois governos é que elas não mantêm nenhuma conexão com, nem derivam das relações comerciais e financeiras do povo inglês com o Brasil, mas as prejudicam" (CLARK, 1865, p. 4-5). 
De fato, no quinquênio 1860-64, o Brasil quase triplicou suas importações de produtos ingleses em relação ao quinquênio anterior. Também houve um aumento expressivo dos empréstimos públicos brasileiros concedidos pela Grã-Bretanha (GRAHAM, 1973, p. 81, 106).

Já o segundo argumento de Clark, o de que o governo também estaria se afastando de seus parlamentares, carecia de maiores fundamentações. 0 que certamente havia, principalmente na Câmara dos Comuns (mas também na Câmara Alta), era o alinhamento de alguns parlamentares liberais - do mesmo partido do governo - com defensores do livre-comércio, que julgavam desastrada a diretriz agressiva do gabinete. Havia também uma aproximação desses parlamentares com a British and Foreign Anti-Slavery Society, que havia estabelecido um acordo informal com o governo brasileiro e passou a pressionar por medidas favoráveis ao restabelecimento das relações diplomáticas e à revogação da Lei Aberdeen. 0 circuito de oposição à ação hostil do gabinete também passava por inúmeros periódicos, inclusive o Times, que publicou um artigo extremamente favorável ao Brasil, e que Clark reproduziu quase na íntegra no seu opúsculo. É difícil, no entanto, avaliar até que ponto houve ingerência do governo e da diplomacia brasileira em todas essas manifestações, ou, então, se elas eram "espontâneas" e simplesmente indicavam uma preocupação com a possível perda de capitais que a manutenção das hostilidades poderia gerar (CLARK, 1865, p. 4-5, 18-20). ${ }^{4}$

De todo modo, o que Clark frisou é que a agressiva diretriz britânica estava contrariando interesses mercantis e financeiros dos próprios britânicos, e o governo precisava revê-la.

Na sequência, Clark traçou uma breve história da formação do Império. De 1822 a 1844, o Brasil passou por uma fase revolucionária, em que

[...] um grande sistema de tráfico de escravos foi organizado por capitalistas estrangeiros associados às antigas influências políticas e sociais, suplantando a inclinação anterior do governo e da sociedade nativa do Império que pretendia se livrar desse tráfico. 0 executivo estava sem recursos pecuniários, legais, policiais ou marítimos adequados para reprimi-lo (CLARK, 1865, p. 6).

Perceba-se a estratégia. 0 sistema de tráfico transatlântico não era obra de brasileiros nativos nem do governo imperial. Toda a "política da escravidão", montada durante o período do Regresso, e que internalizou ilegalmente centenas de milhares de escravos era jogada na conta dos estrangeiros (portugueses), que possuiriam naquela época enorme ascendência sobre a administração brasileira.

\footnotetext{
4 Ainda está para ser realizada uma pesquisa nos arquivos do Itamaraty para avaliar a extensão da interferência diplomática brasileira na imprensa e nos grupos britânicos com interesses financeiros e comerciais no Brasil, especialmente na década de 1860, no tocante à questão da diminuição da interferência antiescravista do Estado britânico no Brasil. Também é necessário proceder a uma avaliação mais circunstanciada dos impactos da ação brasileira na imprensa britânica naquela época. 0 artigo em tela puxa apenas um fio dessa meada, que necessita da averiguação de muitas outras fontes.
} 
Os anos de contrabando de escravos foram explicados pela incapacidade do governo brasileiro reprimir esse comércio, incapacidade cuja principal responsável era a própria Inglaterra:

\begin{abstract}
Durante este período - de 1827 a 1845 - os principais produtos do Brasil foram rigidamente excluídos, por impostos proibitivos, do consumo na Inglaterra; ao passo que, em decorrência do tratado com a Inglaterra, os manufaturados e os produtos do Reino Unido foram admitidos no Império com taxas tão baixas que Ihes conferiam praticamente um monopólio, impedindo o aumento das receitas do Império e mantendo suas finanças num estado de déficit contínuo (a vigência do Tratado inglês obrigou o Brasil a reduzir suas tarifas igualmente para todos os outros Estados) e, desta forma, limitando o meio pecuniário do governo brasileiro para reprimir o tráfico de escravos (CLARK, 1865, p. 8).
\end{abstract}

Já em relação à efetiva supressão do tráfico de escravos no início dos anos 1850, Clark preferiu não tomar partido a respeito das suas motivações, porém elencou as versões inglesa e brasileira. 0 que mais Ihe interessava era apontar que longe da supressão do tráfico de escravos representar o declínio da produção brasileira, ela veio acompanhada de uma grande prosperidade, que se refletiu enormemente nas trocas mercantis e financeiras entre Brasil e Inglaterra:

\begin{abstract}
As melhorias materiais entraram na ordem do dia no Brasil; foram feitos empréstimos na Inglaterra para obras públicas; as companhias públicas inglesas encarregaram-se da formação das ferrovias brasileiras; duas dessas linhas já foram construídas, e uma está em processo de conclusão, inteiramente pelo trabalho livre; grandes somas de capital inglês foram investidas no Império; a opinião pública neste país é fortemente favorável ao Brasil; a influência inglesa do melhor tipo aumentava rapidamente; quando, de repente, a Inglaterra ficou surpresa ao saber das sérias disputas entre os governos inglês e brasileiro, surgidas em dezembro de 1862, acerca de questões inteiramente desconectadas de suas desavenças anteriores (CLARK, 1865, p. 13).
\end{abstract}

Mais uma vez, Clark insistiu na estratégia de timbrar de anômalas as atitudes tomadas pelo gabinete inglês no início de 1863 contra o governo brasileiro, uma vez que eram totalmente contrárias aos interesses mercantis e financeiros da Grã-Bretanha. Depois de resumir os fatos oficiais que teriam levado àquelas desinteligências, ele passou a criticar a "ação maliciosa" que incessantemente estava trabalhando para azedar as relações com o Brasil e centrou fogo no ex-ministro britânico, William D. Christie, e nos gabinetes que se recusaram a revogar a Lei Aberdeen (CLARK, 1865, p. 20-21).

Uma vez preparado o terreno, Clark retoricamente perguntou: “Quais são, então, as questões brasileiras que levaram o governo inglês a alimentar sérias divergências com o Brasil, a interferir nos assuntos brasileiros, e em decorrência das quais surgiu a inimizade geral entre os dois governos?". De imediato, ele eliminou a questão do tráfico de escravos, pois esse comércio estava extinto há mais de uma década, como atestavam as próprias autoridades britânicas. Nenhuma divergência relevante havia, portanto, para justificar medidas tão agressivas. 
A partir desse ponto, Clark começou a apresentar uma interpretação da escravidão brasileira, sempre frisando suas diferenças em relação aos dois outros grandes sistemas escravistas americanos. A ideia era mostrar que a diretriz britânica era inconsequente, pois a escravidão no Brasil não era uma instituição indispensável ao funcionamento da sociedade.

A escravidão, é claro, ainda existe no Brasil. Mas a escravidão não é defendida no Brasil como um bem positivo, como uma condição da sociedade que, se não existir, deve ser estabelecida como uma questão de política e de dever; ela não é justificada no Brasil por motivos de humanidade, ou apoiada a partir das Escrituras; ela não está associada à vida e à existência nacionais, como ocorre nos estados sulistas dos Estados Unidos. [...] Atualmente, a escravidão no Brasil não é alimentada, mantida e aumentada pelo tráfico de escravos africanos como ocorre em Cuba, em violação decidida e obstinada dos tratados com a Espanha (CLARK, 1865, p. 21-22).

Essa distinção do caráter da escravidão brasileira em relação a outros países já vinha sendo desenvolvida pela diplomacia brasileira pelo menos desde 1860. 0 mesmo Andrada que recebeu a delegação da BFASS, funcionário da Legação brasileira em Londres, escreveu ou deu informações para a confecção de um artigo que apresentava argumentos muito semelhantes a estes usados por Clark (THE BRAZILIAN EMPIRE, 1860, p. 303-342). No periódico, o artigo não trouxe o nome do autor e nem subtítulo, entretanto, ele foi republicado em forma de panfleto (TREMENHEERE, 1860).

Ou seja, Clark definiu a escravidão brasileira de forma negativa, por aquilo que ela "não é"; novamente, de forma negativa, ela não tinha perspectivas de perpetuação, pois deixou de ser alimentada pelo tráfico. A mensagem era clara, embora a linguagem fosse diplomática e comedida: a escravidão poderia ser eliminada mais facilmente no Brasil do que em outros lugares. Associados a essas não-características, Clark também registrou os avanços na eliminação dessa instituição:

\begin{abstract}
Uma grande proporção dos escravos das cidades no Brasil tem permissão para trabalhar por própria conta, pagando salários aos seus senhores e tem a oportunidade de acumular lentamente os meios para comprar sua liberdade. A legislação do Brasil oferece-lhes excelentes facilidades para alcançar a liberdade; o sentimento público no Brasil é propício a isso. [...] são frequentes as manumissões voluntárias de escravos por seus proprietários. 0 Imperador, por ocasião do casamento da Princesa Imperial com o Conde d'Eu, libertou todos os negros que eram ligados à princesa. Quando, recentemente, o Comitê da Sociedade Antiescravista entregou ao funcionário do Brasil em Londres um Memorial ao Imperador em favor da emancipação, ele declarou estar de acordo com seus pontos de vista; e, embora tenham se passado alguns meses e suas observações tenham circulado por todo Império, ele ainda conserva a confiança do governo imperial, e não apareceu na imprensa brasileira nenhuma censura sobre as observações que ele fez (CLARK, 1865, p. 22-23).
\end{abstract}

Retome-se a argumentação. A escravidão não era considerada pelos próprios brasileiros como um elemento essencial de sua sociedade; o tráfico que a alimentava estava extinto; diferentemente de outros países, no Brasil as manifestações antiescravistas, de acordo com o arrazoado de Clark, eram 
toleradas e até incentivadas pelas autoridades e pelos dispositivos legais. Restava, entretanto, explicar a mudança em relação às décadas anteriores:

\begin{abstract}
E de onde veio essa mudança de sentimento no Brasil? A Independência não emancipou imediatamente o Brasil da influência estrangeira retrógrada. Durante anos, o velho partido continuou a influenciar o curso do Império. Ele estava no gabinete do Imperador, nas deliberações do Legislativo, nos governos provinciais, nos tribunais, na coletoria de impostos, na magistratura, na polícia, em todos os lugares. Ele possuía experiência na administração, justiça, legislação, em todos os departamentos do Estado. Ele continuou o tráfico de escravos africanos, e foi o gênio maligno do país. Todavia, o velho partido não foi eliminado do dia para a noite, a sua redução e repressão gradual tem sido o trabalho do tempo, do crescimento e da consolidação do poder nativo, do aumento do patriotismo e de uma moralidade mais pura, do progresso da educação. E agora que o governo do Brasil em todos os seus ramos se tornou cada vez mais brasileiro, e está cada vez mais nas mãos de homens que olham para o Brasil como o único objeto de suas fortunas e esperanças, o Império está forçando seu caminho entre essas má influências, e está se tornando um Estado realmente livre e independente (CLARK, 1865, p. 23-24).
\end{abstract}

Mais claro, impossível. O governo brasileiro havia mudado de mãos. Os velhos escravistas, de origem estrangeira, perderam terreno e influência diante das mudanças pelas quais passou a sociedade brasileira. Os brasileiros nativos assumiram o poder e não entendiam que a escravidão era um elemento essencial da vida do país. Com o fim do tráfico e as manifestações antiescravistas da própria sociedade, o novo governo tinha plenas condições de colocar o país no rumo da liberdade. Nas palavras de um historiador, diante dos avanços econômicos e sociais produzidos pelo fim do tráfico, os arranjos montados pelos fazendeiros escravistas já não davam conta das novas necessidades do país. Um novo grupo havia assumido o poder e estava disposto a levar adiante uma diretriz comprometida com a liberdade (BLACKBURN, 2013, p. 451).

É preciso ainda apontar que Clark, para fundamentar sua análise, utilizou uma carta do exministro britânico no Rio de Janeiro, James Hudson, que viu na Câmara quase unânime de 1848, 0 motivo da formação do "partido antiescravista" brasileiro (um dos responsáveis, em última instância, segundo o próprio Hudson, pelo fim do tráfico). Ao serem alijados do poder pelas baionetas dos saquaremas, só teria restado aos liberais a possibilidade de se aglutinar em torno de uma causa que tivesse força suficiente para enfrentar o poder oficial. 0 governo brasileiro subestimou a força do "Partido anti-tráfico de escravos, do Rio Grande ao Pará" (CLARK, 1865, p. 24-25). Breve parêntese: Clark parece não ter percebido a incoerência entre essa carta e seu argumento anterior. Se a adesão ao sentimento antiescravista foi decorrência do alijamento do poder político, então não se podia depositar muita confiança nos liberais em relação às medidas emancipacionistas depois que reconquistassem o poder. 
Clark ainda desautorizou algumas iniciativas individuais de parlamentares brasileiros que apresentaram moções ou projetos sobre "questões menores relacionadas à escravidão". Tal como acontecera na Inglaterra, essas iniciativas, embora merecessem reconhecimento, não conseguiam ser bem-sucedidas e corriam o risco de precipitar soluções não-coordenadas. Em suma, o que Clark parecia querer dizer com sua linguagem diplomática e cautelosa é que cabia só ao governo, com toda sua energia e planejamento, organizar a investida contra a instituição. Mesmo uma intenção boa e meritória, quando mal avaliada, poderia colocar a perder todos os esforços para solucionar o problema. Numa palavra, poderia desencadear uma revolução.

\begin{abstract}
Como ocorria na Inglaterra, está ocorrendo no Brasil. A questão da escravidão, para ser tratada com sucesso, deve ser retomada e dirigida pelo governo, não por indivíduos independentes. A abolição da escravidão num país que possui certamente não menos de três milhões de escravos é percebida por todas as pessoas sensatas como uma grande questão prática, que envolve no Brasil uma revolução industrial, senão social, na qual o governo do Império pode evitar encorajar tentativas espasmódicas de precipitar uma solução (CLARK, 1865, p. 26).
\end{abstract}

Provavelmente, a crítica de Clark endereçava-se a parlamentares como os senadores Jequitinhonha e Silveira da Motta, e o deputado Madureira, que ultimamente haviam apresentado projetos individuais sobre questões colaterais à escravidão. Em 1867, Zacarias de Góis, o então presidente do Gabinete, se expressou quase nos mesmos termos: "o governo entendeu, pois, que devia prevenir a iniciativa individual, declarando às câmaras, ao país e ao mundo que trata deste objeto" (Anais da Câmara dos Deputados, 7 jun. 1867, p. 66).

Em linhas gerais, essa passagem de Clark reafirmava o grande medo dos reformistas brasileiros, tão claramente formulado por Tavares Bastos em 1862: “como se poderá chegar à abolição sem revolução?". Ainda que não plenamente formulado, o grande mote do Centro Liberal, defendido a partir de 1868, "reforma ou revolução", também já pode ser palidamente vislumbrado nessas linhas de Clark. Além de ser necessário, era do interesse do novo grupo que assumira o poder dar encaminhamento à questão da escravidão - a reforma era imperiosa. Mas o problema era imenso e extremamente delicado, e se houvesse precipitação poderia colocar em perigo todos os esforços de edificação do Império. Por outro lado, se nenhuma iniciativa fosse tomada no sentido de se encaminhar as reformas emancipacionistas, certamente também estourariam revoltas ou revoluções. Portanto, ainda que projetos antiescravistas apresentados individualmente por parlamentares fossem dignos de respeito, o encaminhamento das medidas deveria caber exclusivamente ao governo (BASTOS, 1938, p. 459; ARAÚJ 0, 1979, p. 100). 
E o governo brasileiro, segundo Clark, estava ciente e comprometido com elas. Tanto assim que

[...] gabinete brasileiro, então presidido pelo senhor Zacarias, subiu ao poder em 15 de janeiro de 1864, e, de imediato, procedeu para garantir a liberdade dos emancipados [...] Além disso, esse Ministro [...] instruiu os Presidentes de várias Províncias para que emitissem cartas semelhantes a todos os emancipados que reivindicassem sua liberdade.

[...] Um novo gabinete, presidido pelo Senhor Furtado, que ocupava cargos similares aos ocupados pelo senhor Zacarias, foi formado em 31 de agosto de 1864 . Mas a mudança de ministros não envolveu nenhuma mudança neste assunto e dentro de quatro semanas após sua instalação, o novo Gabinete submeteu ao Imperador um Decreto, pelo qual a liberdade era concedida de imediato a todos os emancipados do Império, independente a quem estivessem submetidos (CLARK, 1865, p. 32).

Embora tivesse havido uma mudança do chefe de governo, a diretriz antiescravista brasileira foi mantida. Os novos detentores do poder a endossavam, ela não era a causa de um único homem.

\section{Conclusão}

No âmbito interno, a ascensão dos liberais ao poder em 1864 favoreceu o início das discussões sobre a adoção de medidas antiescravistas e a consequente implementação de algumas delas. No âmbito internacional, por sua vez, a "Questão Christie" e o rompimento das relações diplomáticas entre Brasil e Grã-Bretanha facilitaram o encaminhamento de algumas reivindicações brasileiras, dentre elas a revogação da Lei Aberdeen, a alteração da hostil diretriz antiescravista britânica e o pedido para que a Grã-Bretanha deixasse de interferir acintosamente nos assuntos domésticos brasileiros. A direção dos negócios do Estado havia mudado de mãos, alegavam os liberais. Eles queriam que lhes fosse concedida a oportunidade de mostrar que eram capazes de levar adiante as medidas antiescravistas. Mas também desejavam que a Grã-Bretanha levasse em consideração as peculiaridades do Brasil e a dificuldade de se implantar tais medidas. Em última instância, o que os liberais pediam é que o caráter e 0 alcance das medidas escravistas deveriam ser estabelecidos exclusivamente pelos brasileiros. Essa, aliás, era uma antiga reivindicação, já claramente formulada na década de 1850 pela Sociedade contra o Tráfico de Africanos e Promotora da Colonização e Civilização dos Indígenas (SCT), quando essa entidade manteve contato com a BFASS (RÉ, 2017, p. 311).

$\mathrm{Na}$ "negociação" da década de 1860, o Brasil deu o primeiro passo e promulgou em 18640 decreto que emancipou os africanos livres. A Grã-Bretanha tomou a iniciativa para que as relações diplomáticas fossem restabelecidas em 1865 e, inegavelmente, mudou sua linguagem e maneira de tratar o Brasil. Em 1869, por iniciativa do governo britânico, a Lei Aberdeen foi revogada quase na 
surdina, praticamente sem debates parlamentares. ${ }^{5}$ Mais ou menos dois anos antes, o Conselho de Estado brasileiro começou a discutir a questão do "elemento servil", que culminaria na Lei do VentreLivre de 1871.

Os artigos que Clark publicou no Daily News e, principalmente, seu opúsculo de 1865 indicam que antes mesmo que as discussões acerca das medidas antiescravistas fossem oficialmente abertas no Brasil, políticos, agentes e representantes diplomáticos brasileiros estavam se esforçando internacionalmente para garantir o apoio britânico e um ambiente político favorável tanto interna quanto externamente.

Os eventos narrados também permitem apontar o equívoco da interpretação historiográfica que sustenta que as leis emancipacionistas do final da década de 1860, mas principalmente a Lei do Ventre-Livre de 1871, foram decisões totalmente domésticas:

Em 1871 o jogo foi todo interno: não havia pressão material externa e não havia mais traficantes. A iniciativa foi sem dúvida da Coroa, secundada pelo gabinete conservador e apoiada na imprensa abolicionista e parte do Partido Liberal. [...] 0 impacto de fatores externos foi determinante até 1850. Em 1871 ele foi mais fantasiado do que real (CARVALHO, 2003, p. 314).

A historiografia já começou a rever essa posição (MARQUESE; SALLES, 2016, p. 121). A Lei do Ventre-Livre de 1871, na verdade, foi o lance final de um jogo que teve início nos primeiros anos da década de 1860. Seguramente, o desfecho poderia ter sido antecipado, mas a Guerra do Paraguai parece ter verdadeiramente atrapalhado a movimentação das peças no tabuleiro. Mas os conhecimentos historiográficos atuais permitem asseverar com bastante confiabilidade que 0 apoio internacional foi vital para o fim da "política da escravidão", tal como montada pelos saquaremas no final da década de 1830.

\section{Referências}

ALONSO, Angela. J oaquim Nabuco: os salões e as ruas. São Paulo: Companhia das Letras, 2006.

ARAÚJ O, J osé Thomas Nabuco de. 0 Centro Liberal. Brasília: Senado Federal, 1979.

BASTOS, Aureliano Cândido Tavares. Cartas do solitário. 3. ed. São Paulo: Companhia Editora Nacional, 1938.

\footnotetext{
5 Os Lordes evitaram debater o projeto de revogação da Lei Aberdeen, pois "não valia a pena discutir toda a questão, mais particularmente porque o único efeito prático desses discursos seria despertar na mente dos brasileiros a ideia de que eles tinham razão de fazer fortes reivindicações contra a injustiça internacional cometida contra seu país" (Hansard, HL Deb 02 March 1869 vol 194 cc47181).
} 
BETHELL, Leslie. A abolição do tráfico de escravos no Brasil: a Grã-Bretanha, o Brasil e a questão do tráfico de escravos, 1807-1869. Rio de Janeiro: Expressão e Cultura, 1976.

BLACKBURN, Robin. The American Crucible: slavery, emancipation and human rights. London: Verso, 2013.

BURLINGHAM, Russell; BILLIS, Roger. Reformed characters: the Reform Club in History and Literature. An anthology with commentary. London: Reform Club, 2005.

BURTON, Richard. Viagem do Rio de J aneiro a Morro Velho. Brasília: Senado Federal, 2001.

CARVALHO, Antônio Gontijo de. Um ministério visto por dentro: cartas inéditas de João Batista Calógeras, alto funcionário do Império. Rio de Janeiro: José Olympio, 1959.

CARVALHO, José Murilo de. A construção da ordem: a elite imperial. Teatro de sombras: a política imperial. Rio de J aneiro: Civilização Brasileira, 2003.

CHRISTIE, William Dougal. Notes on Brazilian questions. London: Macmillan \& Co., 1865.

CHRISTIE, William Dougal. The Brazil correspondence in the cases of the "Prince of Wales" and officers of the "Forte". (Reprinted from the Papers laid before Parliament). With an Introduction telling some truth about Brazil. London: William Ridgway, 1863.

CLARK, William Henry. The relations of the British and Brazilian governments. London: Chapman and Hall, 1865.

CONRAD, Robert. Os últimos anos da escravatura no Brasil: 1850-1888. 2. ed. Rio de Janeiro: Civilização Brasileira, 1978.

ELTIS, David. Economic growth and the end of the transatlantic slave trade. New York: Oxford University Press, 1987.

GRAHAM, Richard. Grã-Bretanha e o início da modernização no Brasil: 1850-1914. São Paulo: Brasiliense, 1973.

GRAHAM, Richard. Os fundamentos da ruptura de relações diplomáticas entre o Brasil e a GrãBretanha em 1863: "A Q uestão Christie". Revista de História, São Paulo, v. 24, n. 49, p. 117-138, 1962.

HUGH, Thomas. The Slave Trade: the history of the Atlantic Slave Trade, 1440-1870. Nova York: Touchstone, 1997.

INTERNATIONAL EXHIBITION 1862. Official Catalogue of the Industrial Department. 2nd. ed. London: Truscott, Son \& Simmons, 1862.

LYRA, Heitor. História de Dom Pedro II. Belo Horizonte: Itatiaia; São Paulo: Edusp, 1977. v. 2.

MAMIGONIAN, Beatriz Gallotti. Africanos livres: a abolição do tráfico de escravos no Brasil. São Paulo: Companhia das Letras, 2017.

MARQUESE, Rafael; SALLES, Ricardo. A escravidão no Brasil oitocentista: história e historiografia. In: MARQUESE, Rafael; SALLES, Ricardo (org.). Escravidão e capitalismo histórico no século XIX: Cuba, Brasil, Estados Unidos. Rio de Janeiro: Civilização Brasileira, 2016. p. 99-161. 
MENDONÇA, Renato. Um diplomata na Corte de Inglaterra: o Barão de Penedo e sua época. Brasília: Senado Federal, 2006.

NABUCO, J oaquim. Minha formação. Brasília: Editora UnB, 1963.

NEEDELL, J effrey D. The Party of Order: the Conservatives, the State, and Slavery in the Brazilian Monarchy, 1831-1871. Stanford: Stanford University Press, 2006.

PARRON, Tâmis. A política da escravidão no Império do Brasil: 1826-1865. Rio de Janeiro: Civilização Brasileira, 2011.

RÉ, Henrique Antonio. Uma missão abolicionista britânica no Brasil e as relações entre a British and Foreign Anti-Slavery Society e a Sociedade contra o Tráfico de Africanos e Promotora da Colonização e Civilização dos Indígenas. Almanack, Guarulhos, n. 15, p. 293-317, jan./abr. 2017.

SALLES, Ricardo. E o Vale era o escravo: Vassouras, século XIX: senhores e escravos no coração do Império. Rio de Janeiro: Civilização Brasileira, 2008.

SILVA, J oão Manuel Pereira da. Memórias do meu tempo. Brasília: Senado Federal, 2003.

THE BRAZILIAN EMPIRE. The Quarterly Review, London, v. 108, p. 303-342, jul./oct. 1860.

TREMENHEERE, J. H. The Brazilian Empire: an account of its history, government, slave trade, etc. London: John Murray, 1860.

ZENHA, Celeste. Imagens do Brasil civilizado na imprensa internacional: estratégias do Estado Imperial. Cadernos do CHDD, Brasília, v. 1, n. 2, p. 423-438, 2003.

\section{Fontes}

Anais da Câmara dos Deputados

Anais do Senado

Collecção das Leis do Imperio do Brasil

Correio Mercantil

Daily News

Hansard. House of Lords

Jornal do Commercio

National Archives, Serie F.0. 84

o Correio da Tarde: J ornal Commercial, Politico, Litterario e Noticioso

The Anglo-Brazilian Times

The Anti-Slavery Reporter

Recebido em 20/09/2018

Aprovado em 21/11/2018 